\title{
Pengaruh Industry Expertise, Responsiveness, dan Due Professional Care Audit Internal terhadap Kepuasan Pengguna Jasa Audit dengan Kualitas Audit sebagai Variabel Pemoderasi di PT. Pertani Indonesia
}

\author{
Surisman ${ }^{1}$, Dadang Sadeli ${ }^{2}$ \\ ${ }^{1}$ Universitas Pancasila, Jl. Srengseng Sawah, Jagakarsa, Jakarta Selatan 12640 \\ ${ }^{2}$ Universitas Pendidikan Indonesia, Jl. Dr. Setiabudhi No. 229 Bandung 40381 Jawa Barat
}

I N F O A R T I K E L

JEL Classification:

M42

H83

Keywords:

industry expertise,

responsiveness,

due professional care,

quality audits and

user satisfaction

audit services.

\section{$A \begin{array}{lllllll}A & S & T & R & A & C & T\end{array}$}

This study aims to examine and study empirically, that audit quality may moderate the influence of industry expertise, responsiveness and due professional care to audit user satisfaction in achieving corporate goals at PT. Pertani (Persero) All Indonesian and Subsidiaries. The sample used in this study is the management of upper, middle and lower on PT.Pertani (Persero) All Indonesian and its subsidiaries. Collecting data through questionnaires, with purposive sampling technique in sample selection. The number of questionnaires were answered and eligible to be processed as many as 90 pieces of 125 sent. While the methods of data analysis using the method of least squares multiple regression model, residual test analysis approach. Statistical tests using test analysis approach residual $\beta$ coefficient values obtained variable user satisfaction audit services with a negative value with a significance level of less than 0.05.

\section{A B S T R A K}

Penelitian ini menguji peran kualitas audit sbegai variabel pemoderasi pada pengaruh industry expertise, responsiveness, dan due professional care audit internal terhadap kepuasan pengguna jasa audit pada PT. Pertani Persero Indonesia. Pengujian dilakukan pada 90 responden yang datanya lengkap dan dapat dianalisis. Teknik pengujian variable pemoderasi menggunakan teknik residual model, dimana variable dikatakan sebagai moderator bila pengaruh terhadap nilai residual model utamanya negative dan signifikan. Hasil penelitian menunjukkan bahwa kualitas audit terbukti memoderasi pengaruh expertise, responsiveness, dan due professional care audit internal terhadap kepuasan pengguna jasa audit. Hasil penelitian diharapkan memberikan kontribusi secara empiris bahwa kualitas audit merupakan hal penting yang mampu menentukan kepuasan pengguna jasa audit. 


\section{Pendahuluan}

Seiring dengan perkembangan ekonomi global yang semakin komplek, perusahaan BUMN dituntut melaksanakan prinsip-prinsip profesionalisme, efisiensi, transparansi, kemandirian, akuntabilitas, pertanggungjawaban, serta kewajaran dalam aktivitas pengelolaan usahanya sesuai dengan tata kelola usaha secara sehat. Keberadaan auditor internal atau Satuan Pengawasan Interen (SPI) BUMN untuk membantu manajemen dalam mencapai tujuan organisasi. Auditor internal dalam menjalankan aktivitas auditnya harus mempunyai sikap yang industry expertise, responsiveness dan due professional care yang dapat memberikan nilai tambah bagi manajemen. Dengan demikian internal auditor diharapkan dapat memberikan masukan-masukan yang dapat meningkatkan kinerja perusahaan seperti rekomendasi hasil audit. Oleh karena itu auditor internal dituntut untuk bekerja secara professional. Agar dapat bekerja secara profesional, auditor internal harus memiliki pengetahuan tentang kegiatan dari manajemen, tujuan yang hendak dicapai oleh manajemen dan paham dengan kebutuhan manajemen. Dalam upaya memberikan jawaban dari masalah yang dialami oleh perusahaan dengan rekomendasi-rekomendasinya.

Banyak kritik dari pengguna jasa audit, baik masyarakat, pemerintah, dan pihak lain yang berkepentingan dengan jasa audit. Kritikkritik tersebut mengindikasikan ketidakpuasan pengguna jasa audit terhadap layanan jasa audit dan kualitas audit yang diberikan oleh akuntan eksternal maupun internal, sehingga banyak keinginan dari pihak-pihak yang berkepentingan untuk memonitor pekerjaan dan peningkatan kualitas proses audit. Agar dapat memberikan kepuasan bagi pengguna jasa audit internal, terdapat beberapa hal yang mempengaruhi jasa audit internal adalah industry expertise, responsiveness dan due professional care dan didukung oleh kualitas audit internal. Kualitas audit internal merupakan ukuran kualitas pelaksanaan tugas audit, dalam memenuhi tanggungjawab profesi dari auditor internal terhadap pengguna jasa audit. Kualitas audit internal dapat diukur dari standar kerja, rekomendasi hasil audit dan tindak lanjut dari hasil audit sebagaimana yang dijelaskan (SPAI 2004).

Sejalan dengan peran audit internal dalam meningkatkan pelayanan jasa audit yang dapat memberikan nilai tambah bagi perusahaan, maka peran auditor internal bagi perusahaan sangatlah penting. Hal tersebut juga berlaku bagi perusahaan BUMN, sesuai dengan amanat Undang-Undang (UU) Nomor 19 Tahun 2003 tentang BUMN pada Bab VI, Pasal 67 ayat 1 berbunyi: "Pada setiap BUMN dibentuk satuan pengawasan intern yang merupakan aparat pengawas intern perusahaan." Hal ini berarti mewajibkan setiap BUMN untuk membentuk Satuan Pengawasan Intern (SPI) yang tidak lain merupakan Auditor Internal. Dan sesuai pasal 68 yang berbunyi: "Direksi wajib memperhatikan dan segera mengambil langkah-langkah yang diperlukan atas segala sesuatu yang dikemukakan dalam setiap laporan hasil pemeriksaan yang dibuat oleh satuan pengawasan intern."

Sudah ada beberapa penelitian terdahulu melakukkan penelitian mengenai kepuasan klien, baik kualitas audit eksternal maupun kualitas audit internal, yang meliputi penelitian yang telah dilakukan oleh Hardiningsih (2010) dan Yuniarti (2013). Penelitian Bhen et al., (1997), mencoba menghubungkan kualitas audit dengan kepuasan klien. Hasil penelitian Behn et al., (1997) adalah ada enam atribut kualitas audit yang berpengaruh secara signifikan terhadap kepuasan klien yaitu: pengalaman melakukan audit, memahami industri klien, responsive atas kebutuhan klien, taat pada standar umum, keterlibatan pimpinan KAP, dan keterlibatan komite audit dan due professional care tidak berpengaruh secara siknifikan terhadap kepuasan klien.

Mengacu pada beberapa penelitian terdahulu yang berkaitan dengan kualitas audit yang dirasakan dan kepuasan audit pada privat sektor dan publik sektor. Sepengetahuan peneliti 
masih terbatasnyajumlah penelitian di Indonesia yang menilai industry expertise, responsiveness dan due professional care, dengan kualitas audit internal sabagai pemodrasi dengan melihat dari sisi yang kepuasan yang dirasakan pengguna jasa audit internal, dan juga terbatasnya penelitian yang menilai kepuasan pengguna jasa audit internal. Berdasarkan latar belakang permasalahan diatas dapat dirumuskan dalam penelitian ini adalah sebagai berikut:

1. Apakah kualitas audit dapat memoderasi pengaruh industry expertise terhadap kepuasan pengguna jasa audit?

2. Apakah kualitas audit dapat memoderasi pengaruh responsiveness terhadap kepuasan pengguna jasa audit?

3. Apakah kualitas audit dapat memoderasi pengaruh due professional care terhadap kepuasan pengguna jasa audit?

\section{Telaah Teori dan Pengembangan Hipotesis}

\subsection{Theory of Planned Behavior}

Pada dasarnya teori ini merupakan fungsi dari tiga dasar determinan (Ajzen, 2005). Pertama, terkait dengan sikap dasar seseorang (person in nature) disebut dengan attitude toward the behavior (sikap seorang terhadap perilaku). Kedua menggambarkan pengaruh sosial (sosial influence) yang disebut norma subjektif (subjective norm). Ketiga yang berkaitan dengan isu kontrol (issues of control) yang disebut dengan perceived behavioral control (persepsi mengenai kontrol perilaku).

\subsection{Auditing, Audit Internal dan Kualitas Audit}

Auditing menurut Soekrisno Agoes (2012:1) yang didefinisikan adalah: "Suatu proses sistematis untuk secara objektif mendapatkan dan mengevaluasi bukti mengenai asersi tentang kegiatan-kegiatan dan kejadiankejadian ekonomi untuk meyakinkan tingkat keterkaitan antara asersi tersebut dan kriteria yang telah ditetapkan dan mengkomunikasikan hasilnya kepada pihak-pihak yang berkepentingan"

Menurut Standar Profesi Audit Internal (SPAI-YPIA 2004;9) memberikan definisi Audit Internal adalah sebagai berikut: "Audit internal adalah kegiatan assurance dan konsultasi yang independen dan objektif, yang dirancang untuk memberikan nilai tambah dan meningkatkan operasi organisasi. Audit internal membantu organisasi mencapai tujuannya, melalui suatu pendekatan yang sistematis dan teratur untuk mengevaluasi dan meningkatkan efektivitas pengelolaan risiko, pengendalian dan proses governance" Dari uraian definisi di atas dapat disimpulkan bahwa pengertian audit internal adalah kegiatan atau aktivitas yang memberi keyakinan dan konsultasi yang independent dan obyektifyang di rancang untuk memberikan nilai tambah dan meningkatkan kegiatan oprasional organisasi, berupa informasi yang diberikan oleh auditor dapat menghasilkan rekomendasi yang diaplikasikan oleh pihak manajemen dalam mengelola kegiatan atau program perusahaan, sehingga akan meningkatkan dan memperbaiki kinerja manajemen.

Audit internal yang berkualitas akan mampu mendeteksi penyimpangan dan menginformasikan secara tepat kepada manajemen (Coram, Ferguson \& Moroney, 2006; Kinsella, 2010 ; Domnisory \& Vinatoru, 2008), dan manajemen dapat merespons atau menindaklanjuti adanya kelemahan tersebut secara tepat (Russell \& Regel, 1996 dalam Dityatama 2012). Dari definisi tersebut bahwa kualitas audit internal adalah kemampuan auditor internal mendeteksi penyimpangan dan menginformasikan secara tepat kepada manajemen dan manajemen dapat merespons atau menindaklanjuti adanya kelemahan tersebut secara tepat.

\subsection{Industry Expertise, Responsiveness dan Due Professional Care}

Pada umumnya dalam pelaksanaan audit internal banyak dipengaruhi oleh industry expertise, responsiveness dan due professional 
care. Dalam konteks audit eksternal industry expertise, menurut Arens et.al ( 2008 : 275) auditor harus memiliki pemahaman yang memadai atas bisnis klien, dan pemahaman yang menyeluruh atas bisnis dan industri klien serta pengetahuan tentang operasi perusahaan sangat penting untuk melaksanakan audit yang memadai. Sedangkan menurut Standar Atribut 1220 SPIA yang menyatakan due professionl care bahwa internal auditor harus menerapkan keterampilan dan ketelitian dengan kehati hatian dan kompetensi yang layak dari seorang auditor. Dan menurut Behn et al (1997) pengertian responsiveness adalah tanggap terhadap kebutuhan yang diaudit.

\subsection{Kepuasan Pengguna Jasa Audit}

Menurut Kotler (2008) definisi kata ke- puasan adalah sebagai perasaan senang ataupun kecewa seseorang yang timbul karena membandingkan kinerja yang dipersepsikan produk (atau hasil) terhadap ekspektasi mereka. Dari definisi kepuasan tersebut mengandung pengertian bahwa kepuasan merupakan fungsi kinerja yang dipersepsikan dengan harapan. Jika kinerja jauh dari harapan, maka pemakai atau pelanggan tidak akan puas. Sebaliknya, jika kinerja sesuai dengan harapan, maka pemakai akan sangat puas.

Beberapa hasil penelitian sebelumnya tentang Pengaruh Industry Expertise, Responsiveness, dan Due Professional Care Audit Internal terhadap Kepuasan Pengguna Jasa Audit sebagaimana tampak pada table berikut:

Tabel 1

Ringkasan Penelitian Terdahulu

\begin{tabular}{|c|c|c|c|c|}
\hline No & $\begin{array}{c}\text { Nama \& } \\
\text { Tahun }\end{array}$ & Judul Penelitian & Variabel & Hasil \\
\hline 1 & $\begin{array}{l}\text { Carcello, et.al } \\
\text { (1992) }\end{array}$ & $\begin{array}{l}\text { Audit Quality Attributes: } \\
\text { The Perceptions of Audit } \\
\text { Partners, Prepares, and } \\
\text { Financial Statement Users }\end{array}$ & $\begin{array}{l}\text { Kualitas Audit, } 12 \text { atribut: } \\
\text { - Industry expertise, } \\
\text { - Responsiveness }\end{array}$ & $\begin{array}{l}\text { Karakteristik dari } \\
\text { tim lebih baik dari } \\
\text { karekteristik KAP }\end{array}$ \\
\hline 2 & $\begin{array}{l}\text { Behn et al } \\
(1997)\end{array}$ & $\begin{array}{l}\text { The Determinants of Audit } \\
\text { Client Satisfaction Among } \\
\text { Clients of Big } 6 \text { Firms }\end{array}$ & $\begin{array}{l}\text { Kualitas Audit Dan Pergan- } \\
\text { tian, Auditor, } 12 \text { atribut } \\
\text { diantaranya: } \\
\text { - Industry expertise, } \\
\text { - Responsiveness } \\
\text { - Due professional care }\end{array}$ & $\begin{array}{l}\text { Terdapatnya atribut } \\
\text { industry expertise, } \\
\text { responsiveness yang } \\
\text { berpengaruh secara } \\
\text { signifikan terhadap } \\
\text { kepuasan klien }\end{array}$ \\
\hline 3 & $\begin{array}{l}\text { Ilham } \\
\text { (2001) }\end{array}$ & $\begin{array}{l}\text { Pengaruh Kualitas Audit } \\
\text { Terhadap Kepuasan Peng- } \\
\text { guna Jasa Internal Auditor } \\
\text { di Pertamina. }\end{array}$ & $\begin{array}{l}\text { Kualitas Audit dan } \\
\text { Kepuasan Pengguna Jasa } \\
\text { Internal Auditor, } 10 \text { atribut } \\
\text { diantaranya: } \\
\text { - Industry expertise, } \\
\text { - Responsiveness } \\
\text { - Due professional care }\end{array}$ & $\begin{array}{l}\text { Terdapatnya atribut } \\
\text { kualitas audit } \\
\text { industry expertise, } \\
\text { responsiveness yang } \\
\text { berpengaruh terhadap } \\
\text { kepuasan manajemen } \\
\text { sebagai pengguna } \\
\text { jasa internal auditor }\end{array}$ \\
\hline 4 & $\begin{array}{l}\text { Widagdo } \\
\text { (2002) }\end{array}$ & $\begin{array}{l}\text { Analisis Pengaruh atribut- } \\
\text { atribut kualitas Audit } \\
\text { terhadap kepuasan Klien }\end{array}$ & $\begin{array}{l}\text { Kualitas Audit dan } \\
\text { kepuasan klien atribut dian- } \\
\text { taranya: } \\
\text { - Industry expertise, } \\
\text { - Responsiveness } \\
\text { - Due professional care }\end{array}$ & $\begin{array}{l}\text { Terdapat pengaruh } \\
\text { yang signifikan } \\
\text { antara aribut } \\
\text { kualitas audit } \\
\text { industry expertise, } \\
\text { responsiveness dan } \\
\text { pergantian auditor } \\
\text { terhadap kepuasan } \\
\text { klien kantor akuntan } \\
\text { publik }\end{array}$ \\
\hline
\end{tabular}


Dari berbagai litaratur dan hasil penelitian tentang kualitas audit khususnya Behn et al (1997), hasil penelitian Ilham (2001) dan hasil penelitian Widagdo (2002). Dapat dijelaskan model kerangka pemikiran penelitian ini pada gambar 1 . sebagai berikut:

Gambar I.

Model Kerangka Pemikiran

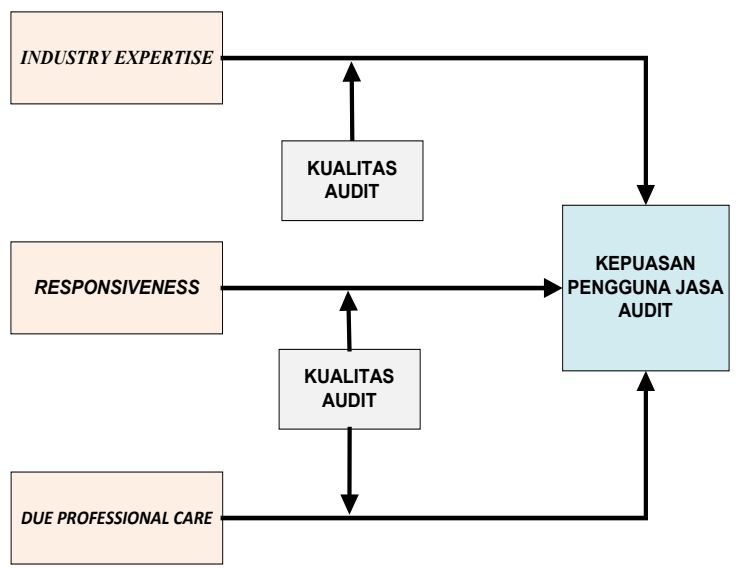

Berdasarkan uraian dari variabel-variabel audit internal pada rerangka pemikiran diatas, masing-masing mempunyai peranan dalam pelaksanaan audit internal untuk menunjang pencapaian tujuan dari perusahaan. Kepuasan pengguna jasa audit atau manajemen ditentukan oleh pelaksanaan audit internal dalam menjalankan jasa auditnya, yang didasarkan pada sikap audit internal yang industry expertise, responsiveness dan due professional care dan didukung oleh audit yang berkualitas. Penilitian yang dilakukan oleh Yuniarti (2013) dengan menguji Audit Quality Attributes and Audit Client Satisfaction dengan hasil penelitian menunjukkan bahwa pemahaman industri klien, responsif terhadap kebutuhan dan sikap kehatian-hatian auditor mempunyai pengaruh yang signifikan terhadap kepuasan klien. Sehubungan dengan hal tersebut, maka dikembangkan hipotesis dengan penjelasan sebagai berikut:

H1 :Kualitas audit dapat memoderasi pengaruh industry expertise terhadap kepuasan pengguna jasa audit.

H2 :Kualitas audit dapat memoderasi pengaruh responsiveness terhadap kepuasan pengguna jasa audit.
H3 : Kualitas audit dapat memoderasipengaruh due professional care terhadap kepuasan pengguna jasa audit.

\section{Metode Penelitian}

Jenis data yang digunakan didalam penelitian ini berupa data primer dan data sekunder. Data primer pada penelitian ini adalah data primer yang dikumpulkan oleh peneliti dengan metode kuesioner yang dikirimkan langsung dengan cara melalui pengiriman pos maupun mendatangi ke tempat kerja responden di PT Pertani (Persero). Sedangkan sumber data yang digunakan dalam penelitian ini adalah jawaban dari manajemen PT Pertani (Persero) seperti ketentuan-ketentuan yang berlaku bagi internal auditor di PT Pertani (Persero) dan ketentuan lainnya yang berlaku yang berkaitan dengan penulisan ini.

Populasi penelitian ini adalah dewan komisaris, pihak manajemen atas, manajemen menengah, manajemen bawah di PT Pertani (Persero) Seluruh Indonesia dan anak perusahaan. Adapun jumlah unit kerja yang melakukan kegiatan operasional di PT Pertani (Persero) sebanyak 130 unit kerja dengan populasi jumlah pejabat sebanyak 285 orang. Dari populasi tersebut pemilihan sampel secara purposive sampling berdasarkan judgement, yaitu pejabat yang akan dijadikan responden, dipilih yang relatif sering berinteraksi dengan audit internal.

Pengumpulan data primer dilakukan dengan metode mail survey melalui kuesioner denganmengirimdaftarpertanyaanyangdiisidan dijawab oleh pejabat level atas, level menengah dan level bawah yang terpilih. Sedangkan data sekunder akan diambil dari laporan-laporan yang diterima dan yang dikeluarkan Internal Audit PT Pertani (Persero). Metode yang digunakan untuk menganalisis data penelitian menggunakan metode kuadrat terkecil dengan model regresi berganda, pendekatan uji residual dengan bantuan program software SPSS. Adapun teknis analisis yang digunakan sebagai berikut: 
1. Statistik Deskriptif

Guna memberikan gambaran mengenai demografi responden penelitian dan deskripsi mengenai variabel penelitian. Peneliti menggunakan tabel distribusi frekwensi yang menunjukkan nilai distribusi data penelitian yang memiliki kesamaan kategori dengan menggunakan tabel distribusi frekuensi absolut yang menunjukkan rata-rata, median dan deviasi standar.

2. Uji Reliabilitas dan Validitas

Uji Kualitas Data untuk mengetahui keabsahan dan kesahihan suatu hasil penelitian dilakukan pengujian terhadap kuesioner dengan menggunakan responden yang relatif kecil yang diambil dari populasi sasaran yaitu sebanyak 74 sampel.

a. Uji Validitas

Uji validitas adalah untuk mengukur sah atau valid tidak suatu kuesioner. Suatu kuesioner dikatakan valid jika pertanyaan pada kuesioner mampu untuk mengungkapkan sesuatu yang akan diukur oleh kuesioner tersebut (Ghozali, 2005). Mengukur tingkat validitas dilakukan dengan melakukan korelasi antara skor butir pertanyaan dengan total skor konstruk atau variabel. Uji signifikansi dilakukan dengan membandingkan nilai $r$ hitung dengan $r$ tabel untuk degree of freedom $(\mathrm{df})=\mathrm{n}-2$. Jika $r$ hitung lebih besar dari $r$ tabel dan nilai $r$ positif maka pertanyaan tersebut dikatakan valid.

b. Uji Reliabilitas

Uji reliabilitis sebenarnya adalah alat untuk mengukur suatu kuesioner yang merupakan indikator dari variabel atau konstruk. Suatu koesioner dikatakan reliabel atau andal jika jawaban responden terhadap pertanyaan konsisten atau stabil (Ghozali,2005). Pengujian reliabilitas dalam penelitian ini menggunakan Cronbach alpha masingmasing instrumen. Variabel tersebut akan dikatakan reliabel bila Cronbach alphanya memiliki nilai lebih besar dari 0,60 Sekaran (2003: 257) yang menyatakan bahwa pada umumnya reliabilitas yang nilai r-nya kurang dari 0,60 dikatakan kurang reliabel.

3. Uji Asumsi Klasik

a. Uji Normalitas

Uji Normalitas bertujuan untuk menguji apakah dalam model regresi, variabel pengganggu atau residual memiliki distribusi normal (Ghozali 2005:110). Ada dua cara untuk mendeteksi apakah residual berdistribusi normal atau tidak yaitu dengan analisa statistik. Dalam penelitianiniUjinormalitasdatadilakukan melalui 2 cara yaitu menggunakan $\mathrm{Uji}$ Kolmogorof-Smirnov (Uji K-S), dan kurva penyebaran P-Plot. Untuk Uji K-S yakni jika nilai hasil Uji K-S > dibandingkan taraf signifikansi 0,05 , maka sebaran data tidak menyimpang dari kurva normalnya itu uji normalitas. Sedangkan melalui pola penyebaran $\mathrm{P}$ Plot yakni jika pola penyebaran memiliki garis normal, jika distribusi data adalah normal, maka garis yang menggambarkan data sesungguhnya akan mengikuti garis diagonalnya maka dapat dikatakan data berdistribusi normal.

b. Uji Multikolinieritas

Uji multikolinieritas bertujuan untuk menguji apakah model regresi ditemukan ada korealasi antara variabel independen. Model yang baik seharusnya tidak terjadi korelasi antara variabel independen (Ghozali, 2005 95). Untuk mendeteksi ada atau tidaknya multikolinieritas dalam model regresi dalam peneilitian ini dilakukan dengan cara melihat dari nilai Variance Inflation Factor (VIF) tidak lebih dari 10 dan Tolerance tidak kurang dari 0,1 , maka model dapat dikatakan terbebas dari multikolinieritas VIF $=1 /$ Tolerance.

c. Uji Heteroskedastisitas 
Uji heteroskedastisitas bertujuan untuk menguji apakah dalam model regresi terjadi ketidaksamaan variance dari residual suatu pengamatan ke pengamatan yang lain. Ada tidaknya heteroskedastisitas dapat dilihat dari : Melihat dari grafik plot, jika titik-titik yang ada membentuk suatu pola tertentu yang teratur (bergelombang), maka terjadi heteroskedastisitas. Jika tidak ada pola yang jelas, titik-titik menyebar di atas dan di bawah angka nol pada sumbu Y, maka tidak terjadi heteroskedastisitas. (Ghozali,2005:105).Ujikoefisienkorelasi Spearman's rho yaitu mengkorelasikan variabel independen dengan residualnya. Jika korelasi antara variabel independen dengan residual memberikan signifikansi lebih dari 0,05 , maka dapat dikatakan tidak terjadi heteroskedasitas.

4. Uji Hipotesis

Pengujian hipotesis menggunakan metode kuadrat terkecil dilakukan dengan bantuan komputer program SPSS dengan melibatkan variabel moderating dapat dilakukan dengan menggunakan uji residual. Pertimbangan menggunakan uji residual dalam analisis data disebabkan adanya kecenderungan pengujian variabel moderating dengan uji interaksi maupun uji nilai selisih mutlak absolut akan terjadi multikolinearitas yang tinggi antar variabel independen dan hal ini akan menyalahi asumsi klasik dalam regresi ordinary least square (OLS). Analisis residual ingin menguji pengaruh deviasi (penyimpangan) dari suatu model. Fokusnya adalah ketidak cocokan (lack of fit) yang dihasilkan dari deviasi hubungan linear antar variabel independen dan moderat. Lack of fit ditunjukkan oleh nilai residual didalam regresi.

Langkah uji residual dapat dilakukan dengan persamaan regresi berganda berikut ini.

$$
\mathrm{X} 4=\mathrm{a}+\beta 1 \mathrm{X} 1 / \beta 2 \mathrm{X} 2 / \beta 3 \mathrm{X} 3+\mathrm{e} \quad \ldots
$$

(persamaan 1)

$|\mathrm{e}|=\mathrm{a}+\beta 4 \mathrm{Y}$

(persamaan 2)

Keterangan:

$\mathrm{Y}=$ Kepuasan Pengguna Jasa Audit

$\mathrm{X} 1=$ Industry expertise

$\mathrm{X} 2$ = Responsiveness

$\mathrm{X} 3$ = Due professional care

X4 = Kualitas Audit

$\mathrm{a}=$ Konstanta

$\beta \mathrm{n}=$ Koefisien regresi $\mathrm{n}$

$|\mathrm{e}|=$ AbsRes_n(nilai absolut dari residual industry expertisel responsiveness/due professional care terhadap kualitas audit)

$\mathrm{e} \quad=$ error $I$

Hipotesis statistiknya:

- H0: $\beta 4=0$ jika koefisien $\beta 4$ positif dan signifikansi $>0,05$ tolak

- Ha: $\beta 4 \neq 0 \quad$ jika koefisien $\beta 4$ negatif dan signifikansi $<0,05$ diterima

$$
\text { Persamaan regresi }
$$

menggambarkan apakah variabel Kualitas Audit merupakan variabel moderating, ditunjukkan dengan nilai koefisien $\beta 4$ Kepuasan Pengguna Jasa Audit. Apabila nilai koefisien $\beta 4$ Kepuasan Pengguna Jasa Audit hasilnya negatif dan signifikansi kurang dari $<0,05$, maka dapat disimpulkan bahwa Kualitas Audit merupakan variabel moderating, yang memoderasi pengaruh industry expertise/ responsiveness/due professional care terhadap Kepuasan Pengguna Jasa Audit, sebaliknya jika koefisien $\beta 4$ Kepuasan Pengguna Jasa Audit hasilnya tidak negatif dan atau tidak signifikan, maka Kualitas Audit bukan merupakan variabel moderating.

\section{Hasil Penelitian dan Pembahasan \\ 4.1 Hasil Penelitian}

Pembahasan hasil dari studi lapangan untuk memperoleh data dengan menggunakan kuesioner untuk mengukur lima variabel pokok 
dalam penelitian ini, yaitu industry expertise, responsiveness, due professional care, kepuasan pengguna jasa audit dan kualitas audit. Hasil uji diskriptif statistik menunjukkan kisaran angka teoritis dan kisaran sesungguhnya, rata-rata standar deviasi dapat diketahui jumlah sampel sebanyak 90 responden dari masing-masing variabel INDEX mempunyai nilai minimum sebesar 12,00, nilai maksimum sebesar 15,00,
Uji Reliabilitas diukur dengan cara menghitungbesarnyanilaiCronbachalpha. Nilai Cronbach alpha menunjukkan reliabel apabila nilainya lebih besar dari 0,60 (Ghozali,2005). Suatu kuisioner dikatakan reliabel atau handal jika jawaban seseorang terhadap pertanyaan adalah konsisten atau stabil dari waktu ke waktu. Hasil penujian reliabilitas masingmasing variabel adalah sebagai berikut:

Tabel 2

Hasil Uji Reliabilitas

\begin{tabular}{lllll}
\hline Industry Expertise & 0,752 & 0,752 & 0,60 & Reliabel \\
Responsiveness & 0,720 & 0,720 & 0,60 & Reliabel \\
Due Professional Care & 0,647 & 0,647 & 0,60 & Reliabel \\
Kualitas Audit & 0,790 & 0,790 & 0,60 & Reliabel \\
Kepuasan Pengguna Jasa Audit & 0,836 & 0,836 & 0,60 & Reliabel \\
\hline
\end{tabular}

rata-rata sebesar 14,2778 dan deviasi standar sebesar 1,07084. Variabel RES mempunyai nilai minimum sebesar 7,00 , nilai maksimum sebesar 15,00 , rata-rata 12,7778 , dan deviasi standar sebesar 1,82232. Selanjutnya, variabel DUE mempunyai nilai minimum sebesar 8,00 , nilai maksimum sebesar 10,00 , rata-rata 9,3889, dan standar deviasi sebesar 0.81688 . Variabel KUA mempunyai nilai minimum sebesar 20,00, nilai maksimum sebesar 30,00, rata-rata 27,1000 , dan standar deviasi sebesar 2,38464 . Sedangkan variabel $P U A S$ mempunyai nilai minimum sebesar 24,00 , nilai maksimum sebesar 40,00, rata-rata 35,1667 , dan standar deviasi sebesar 3,39282.

Uji validitas dilakukan dengan melihat Pearson correlation antara score masingmasing pertanyaan dengan total score $>\mathrm{r}$ tabel product moment dengan signifikansi 0,05. Suatu kuesioner dikatakan valid jika pertanyaan pada kuesioner mampu untuk mengungkapkan sesuatu yang akan diukur oleh kuesioner tersebut. Berdasarkan hasil pengujian validitas menunjukkan bahwa korelasi antara masingmasing indikator terhadap total skor konstruk menunjukkan korelasi $>0,2072$ atau hasilnya signifikan $<0,05$. Jadi dapat disimpulkan bahwa masing-masing indikator pertanyaan adalah valid.
Berdasarkan hasil pengujian reliabilitas tabel diatas dengan program SPSS, menunjukkan bahwa Cronbach alpha masingmasing variabel nilainya lebih besar dari 0,60 , jadi dapat disimpulkan semua variabel adalah reliabel. Selanjutnya, uji normalitas bertujuan untuk menguji apakah dalam model regresi, variabel dependen dan independen keduanya mempunyai distribusi normal atau tidak. Hasil uji normalitas pada tabel diatas dapat jelaskan bahwa nilai $\mathrm{KS}$ sebesar 0,831 dan signifikan sebesar 0,495 atau lebih besar dari 0,05. Dapat ditarik kesimpulan bahwa data residual dalam penelitian ini terdistribusi normal. Uji multikolinieritas digunakan untuk menguji apakah model regresi ditemukan adanya korelasi antar variabel independen. Model regresi yang baik seharusnya tidak terjadi korelasi diantara variabel independen. Ada tidaknya korelasi antar variabel tersebut dapat dideteksi dengan melihat nilai tolerance dan Variance Inflation Factor (VIF). Hasil pengujian menunjukkan nilai Variance Inflantion Factor (VIF) dari variabel industry expertise, responsiveness, due professional care dan kualitas audit memiliki nilai kurang dari 10 dan nilai tolerance lebih dari 0,10 . Sehingga dapat disimpulkan bahwa tidak terjadi.

Untuk menguji gejala heterokedastisitas 
dilakukan dengan melihat penyebaran residual hasil estimasi model yang dipaparkan dalam scatterplot, jika penyebarannya acak atau tidak membentuk pola maka dapat dikatakan tidak terjadi heterokedastisitas. Hasil ini dipertegas dengan uji statistik berupa teknik uji koefisien korelasi Spearman's rho yaitu mengorelasikan variabel independen dengan residualnya (Priyatno 2008), dengan hasil pengujian menunjukkan bahwa korelasi antara variabel industry expertise, responsiveness, due professional care dan kualitas audit dengan Unstandardized Residual memiliki nilai signifikasi lebih dari 0,05 maka dapat disimpulakan bahwa tidak terjadi heteroskedastisitas.

Pengujian hipotesis menggunakan metode kuadrat terkecil yang dalam bentuk analisis modelregresiberganda, yang melibatkan variabel moderating dapat dilakukan dengan pendekatan analisis uji residual dengan hasil uji sebagai berikut: Hasil pengujian terhadap keofisien deteminasi terhadap hubungan variabel independen dan moderating secara bersamaan adalah sebagai berikut:

\section{Tabel 3}

\section{Koefisien Determinasi}

Model Summaryb

\begin{tabular}{|c|c|c|c|c|c|}
\hline Model & $\mathbf{R}$ & R Square & $\begin{array}{l}\text { Adjusted } \\
\text { R Square }\end{array}$ & $\begin{array}{c}\text { Std. Error } \\
\text { of the } \\
\text { Estimate }\end{array}$ & $\begin{array}{l}\text { Durbin - } \\
\text { Watson }\end{array}$ \\
\hline 1 & $.850^{\mathrm{a}}$ & .723 & 1.82714 & 1.624 & .710 \\
\hline
\end{tabular}

Sumber: data primer (diolah, 2014)

Dari hasil pengujian pada tabel diperoleh besaran adjusted $\mathrm{R}^{2}$ sebesar 0,710 yang berarti bahwa $71,00 \%$ kepuasan pengguna jasa audit dapat dijelaskan oleh variabel industry expertise, responsiveness, due professional care dan kualitas audit dan sisanya dijelaskan oleh sebab-sebab diluar model ini. Ringkasan hasil uji moderasi dengan teknik residual seperti tampak pada Tabel berikut:
Tabel 4

Rangkuman Hasil Uji Interaksi Residual

\begin{tabular}{|c|c|c|c|c|c|c|}
\hline \multirow{2}{*}{ Variabel } & \multicolumn{2}{|c|}{ Hipotesis 1} & \multicolumn{2}{|c|}{ Hipotesis 2} & \multicolumn{2}{|c|}{ Hipotesis 3} \\
\hline & PUAS & Absres1 & PUAS & Absres2 & PUAS & 8 \\
\hline \multirow[t]{2}{*}{ PUAS } & 0.002 & 0.023 & & 0.003 & & 0.021 \\
\hline & & $(-2.322)$ & & $(-3.035$ & & $(-2.348)$ \\
\hline INDEX & 0.000 & & & & & \\
\hline KUA & - & & 0.000 & - & 0.000 & - \\
\hline DUE & - & & - & - & 0.049 & - \\
\hline
\end{tabular}

Hasil uji hipotesis pertama diperoleh nilai signifikansi secara individu dari industry expertise sebesar 0,002 dan kualitas audit sebesar 0,000 lebih kecil dari 0,05. Pengujian hipotesis pertama yang dilakukan dengan menggunakan pendekatan residual. Darihasil outputSPSS pada tabel diatas diperoleh nilai koefisien $\beta$ variabel PUAS (Kepuasan Pengguna Jasa Audit) nilai negatif $-0,080$ dengan signifikansi 0,023 lebih kecil dari 0,05. Dengan nilai koefisien parameter $\beta$ Kepuasan Pengguna Jasa Audit yang negatif dan signifikan, menunjukan bahwa variabel kualitas audit merupakan variabel moderating, berarti hipotesis pertama $\mathrm{Ha}$ diterima dan dapat disimpulkan bahwa kualitas audit dapat memoderasi pengaruh industry expertise secara signifikan terhadap kepuasan pengguna jasa audit.

Hasil uji hipotesis kedua, diperoleh nilai signifikansi secara individu dari responsiveness sebesar 0,003 dan kualitas audit sebesar 0,000 lebih kecil dari 0,05 . Pengujian hipotesis kedua yang dilakukan dengan menggunakan pendekatan residual. Darihasil outputSPSS pada tabel diatas diperoleh nilai koefisien $\beta$ variabel PUAS (Kepuasan Pengguna Jasa Audit) nilai nigatif $-0,119$ dengan signifikansi 0,003 lebih kecil dari 0,05. Dengan nilai koefisien parameter $\beta$ Kepuasan Pengguna Jasa Audit yang negatif dan signifikan, menunjukan bahwa variabel kualitas audit merupakan variabel moderating, berarti hipotesis kedua Ha diterima dan dapat disimpulkan bahwa kualitas audit dapat memoderasi pengaruh responsiveness secara signifikan terhadap kepuasan pengguna jasa audit. Hasil uji hipotesis ketiga, diperoleh nilai 
signifikansi secara individu dari due professional care sebesar 0,049 dan kualitas audit sebesar 0,000 lebih kecil dari 0,05. Pengujian hipotesis ketiga yang dilakukan dengan menggunakan pendekatan residual. Dari hasil output SPSS pada tabel diatas diperoleh nilai koefisien $\beta$ variabel PUAS (Kepuasan Pengguna Jasa Audit) nilai negatif -0,079 dengan signifikansi 0,021 lebih kecil dari 0,05 . Dengan nilai koefisien parameter $\beta$ Kepuasan Pengguna Jasa Audit yang negatif dan signifikan, menunjukan bahwa variabel kualitas audit merupakan variabel moderating, berarti hipotesis ketiga Ha diterima dan dapat disimpulkan bahwa kualitas audit dapat memoderasi pengaruh due professional care secara signifikan terhadap kepuasan pengguna jasa audit. Hasil pengujian menunjukkan bahwa signifikan pengaruh setiap residual model adalah negative signifikan. Hal ini menunjukkan bahwa terbukti bahwa kualitas audit adalah variable pemoderasi.

\subsection{Pembahasan}

Pembahasan mengenai hasil penelitian terhadap hasil uji hipotesis dapat disajikan sebagai berikut: Dari hasil uji hipotesis diatas membuktikan secara empiris bahwa industry expertise berpengaruh terhadap kepuasan pengguna jasa audit. Hasil penelitian ini sejalan dengan penelitian Benh et al, (1997), Ilham, (2001), dan Widagdo (2002). Menunjukan bahwa kualitas audit bukan merupakan variabel independen, melainkan merupakan variabel moderating, yang menguatkan pengaruh industry expertise audit internal terhadap kepuasan pengguna jasa audit. Hasil penelitian ini mengindikasikan bahwa menajemen perusahaan mempersepsikan seorang auditor, harus memiliki pemahaman yang luas atas tujuan dari kegiatan operasional yang dilaksanakan manajemen, yang hendak dicapai oleh manajemen dari kegiatan operasionalnya. Sehingga dengan pemahaman yang luas, dengan pelayanan jasa audit yang berorentasi kualitas audit, dapat memberikan kepuasan bagi manajemen. Hal ini berarti bahwa seorang auditor internal harus dimiliki pemahaman luas terhadap tujuan dari kegiatan operasional yang dilaksanakan manajemen. Tidak saja pemahaman proses audit berkaitan dengan keuangan saja, tetapi juga paham tujuan dari kegiatan operasional atau proses operasional yang hendak dicapai oleh manajemen sebagai pengguna jasa audit, hal tersebut mutlak diperlukan untuk memberikan kepuasan kepada pengguna jasa audit. Semakin meningkat kualitas audit internal, semakin luas industry expertise seorang auditor internal, maka semakin kuat pengaruhnya kepada kepuasan pengguna jasa audit.

Dari hasil uji hipotesis kedua menunjukkan bahwa Kualitas Audit Dapat Memoderasi Pengaruh Responsiveness terhadap kepuasan pengguna jasa audit yang membuktikan secara empiris bahwa responsiveness berpengaruh terhadap kepuasan pengguna jasa audit. Hasil penelitian ini sejalan dengan penelitian Ilham, (2001), Widagdo (2002), Hardiningsih (2010) dan Yuniarti (2013). Menunjukan bahwa kualitas audit merupakan variabel moderating, yang menguatkan pengaruh responsiveness audit internal terhadap kepuasan pengguna jasa audit. Hasil penelitian ini mengindikasikan bahwa menajemen perusahaan mempersepsikan seorang auditor internal, harus memiliki perilaku yang responsif terhadap kebutuhankebutuhan manajemen baik dalam proses audit maupun dalam kegiatan operasional, yang akan dicapai oleh manajemen. Sehingga dengan sikap dan perilaku responsif, dengan pelayanan jasa audit yang berorentasi kualitas audit, maka dapat memberikan kepuasan bagi manajemen. Hal ini berarti bahwa seorang auditor internal harus dimiliki sikap cepat, tanggap dan perhatian terhadap kebutuhan manajemen, hal tersebut mutlak diperlukan untuk memberikan kepuasan kepada pengguna jasa audit. Semakin meningkat kualitas audit internal. Semakin tinggi tingkat responsiveness seorang auditor internal terhadap kebutuhan manajemen, semakin kuat pengaruhnya terhadap kepada kepuasan pengguna jasa audit. 
Dari hasil uji hipotesis ketiga menunjukkan bahwa Kualitas Audit Dapat Memoderasi Pengaruh Due Professional Care Terhadap Kepuasan Pengguna Jasa Audit yang membuktikan secara empiris bahwa due professional care berpengaruh terhadap kepuasan pengguna jasa audit. Hasil penelitian ini sejalan dengan penelitian penelitian Zawitri (2010) dan Yuniarti (2013). Menunjukan bahwa kualitas audit merupakan variabel moderating, yang menguatkan pengaruh due professional care audit internal terhadap kepuasan pengguna jasa audit. Hasil penelitian ini mengindikasikan bahwa menajemen perusahaan mempersepsikan seorang auditor harus bersikap hati-hati dan memiliki kecermatan professional, dalam melaksanakan peroses audit. Sehingga dengan bersikap hati-hati dan memiliki kecermatan professional, dan memberikan pelayanan jasa audit, beroriantasi kualitas audit, dapat memberikan kepuasan bagi manajemen. Hal ini berarti bahwa seorang auditor internal harus dimiliki sikap hati-hati, cermat dan keahlian professional dalam melaksanakan audit, hal tersebut mutlak diperlukan untuk memberikan kepuasan kepada pengguna jasa audit. Semakin meningkat kualitas audit internal, semakin tinggi tingkat due professional care seorang auditor internal dalam melakukan audit dan semakin meningkatkan kepuasan pengguna jasa audit.

\section{Kesimpulan, Keterbatasan Dan Implikasi Hasil Penelitian}

Berdasarkan hasil analisis data dan pengujian hipotesis, maka ditarik kesimpulan yaitu (1). Bahwa Industry expertise, responsiveness, due professional care dan kualitas audit memberikan sumbangan pengaruh sebesar $71,00 \%$ terhadap kepuasan pengguna jasa audit dan sisanya dipengaruhi oleh variabel lain. (2). Bahwa Kualitas audit dapat memoderasi pengaruh industry expertise, responsiveness dan due professional care terhadap kepuasan pengguna jasa audit. Menunjukan semakin luas industry expertise, semakin tinggi tingkat responsiveness dan due professional care seorang auditor internal dan semakin berkualitasnya audit internal, maka semakin meningkatkan kepuasan pengguna jasa audit.

Dalam penelitian ini masih terdapat kelemahan dan keterbatasan yang sulit untuk dihindari dan dapat mempengaruhi penelitian yaitu (1). Obyek penelitian ini terbatasan pada lingkup manajemen PT.Pertani (Persero) Seluruh Indonesia dan Anak Perusahaan. (2). Kepuasan pengguna jasa audit internal tidak hanya dipengaruhi oleh variabel yang digunakan dalam penelitian ini, namun masih terdapat variabel lainya yang diprediksi dapat mempengaruhi. (3). Keterbatasan kemampuan responden untuk memahami isi pernyataan serta kejujuran untuk menjawab kuesioner yang diberikan,kemungkinan kesalahan dalam menjawab dapat terjadi. (4). Data penelitian ini dihasilkan dari instrumen yang mendasarkan pada persepsi dari pihak manajemen, ada kemungkinan sebagian manajemen kurang memahami ruang lingkup perkerjaan auditor internal, sehingga biasa terjadi bias dalam mamahami dan melakukan pengisian kuesioner. (5). Penggunaan metode dalam penelitian ini hanya dengan menggunakan metode mail survey yaitu kuesioner, sehingga memungkinkan terjadinya ketidak jujuran dalam menjawab pertanyaan.

Berdasarkan hasil penelitian, terdapat saran-saran yang dapat dijadikan masukan, dapat memberikan kepusaan pengguna jasa audit yaitu (1). Untuk meningkatkan kepuasan manajemen perusahaan diperlukan adanya peningkatan industry expertise dan responsiveness para auditor internal. (2). Untuk para auditor internal diharapkan meningkatkan due professional care, karena faktor due professional care dapat mempengaruhi tingkat kepuasan manajemen. (3). Auditor Internal untuk selalu meningkatkan perannya sebagai konsultan. (4). Peneliti selanjutnya disarankan menambah variabel penelitian lainnya yang dapat mempengaruhi kepuasan pengguna jasa audit contohnya kompetensi, obyektifitas, integritas dan 
independen yang mungkin mempengaruhi kepuasan pengguna jasa audit. (5). Penelitian akan mendatang, disarankan untuk memperluas obyek yang diteliti, mencakup manajemen perusahan-perusahaan swasta atau BUMN yang mempunyai audit internal, tidak hanya pada perusahaan satu grup saja.

\section{Daftar Pustaka}

Agoes, Sukrisno. 2013 Auditing (Petunjuk Praktis Pemeriksaan Akuntansi oleh Akuntan Publik) Edisi Empat, Fakultas Ekonomi Universitas Indonesia, Jakarta.

Arens and Loebbecke, 2008, Auditing dan Jasa Assurance, Edisi Keduabelas Erlangga, Jakarta

Behn, Bruce K, Joseph V. Carcello, Dana R.Hermanson dan Roger H.Hermanson, 1997, The Determinants of Audit Client Satisfaction Among Clients of Big 6 Firms, Accounting Horizons (March), Vol. 11, No. 1: 7-24.

Hardiningsih, Pancawati, 2010, Pengaruh Kualitas Audit dan Portopolio Jasa Audit Terhadap Kepuasan Klien, Jurnal Dinamika Keuangan dan Perbankan: 47-61

Kotler, P. (2008). Marketing Management: Analysis, planning, Implementation, and Control, 9th ed. Englewood Cliffs,N.J., Prentice Hall International, Inc.

Widagdo, Ridwan. 2002. Analisis Pengaruh atribut-atribut kualitas Audit terhadap kepuasan Klien. Tesis Program Pasca Sarjana Magister Akuntansi Universitas Diponegoro (tidak dipublikasikan).

Yayasan pendidikan Internal Audit. 2004. Standar Profesi Audit Internal. Jakarta. Yayasan pendidikan Internal Audit.

Yayasan pendidikan Internal Audit. 2008. Perencanaan \& Perangkat Penugasan Jakarta. Yayasan pendidikan Internal Audit.

Yuniarti, Rita. Willy Mara Zumara, 2013, Audit Quality Attributes and Audit Client Satisfaction, International Journal of Humanities and Management Sciences:
2320-4044.

Zawitri, Sari. 2009, Analisa Faktor-Faktor Penentu kualitas Audit Yang Dirasakan Dan Kepuasan Auditee Di Pemerintahan Daerah, Tesis Program Pasca Sarjana Magister Akuntansi Universitas Diponegoro (tidak dipublikasikan). 